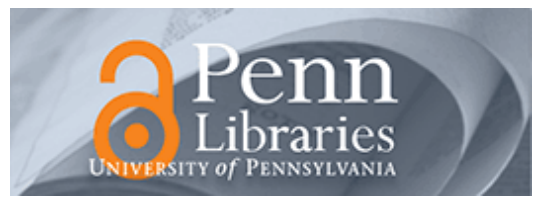

University of Pennsylvania

ScholarlyCommons

Finance Papers

Wharton Faculty Research

6-1986

\title{
The Failure of Ricardian Equivalence Under Progressive Wealth Taxation
}

Andrew B. Abel

University of Pennsylvania

Follow this and additional works at: https://repository.upenn.edu/fnce_papers

Part of the Economics Commons, Finance and Financial Management Commons, and the Taxation Commons

Recommended Citation

Abel, A. B. (1986). The Failure of Ricardian Equivalence Under Progressive Wealth Taxation. Journal of Public Economics, 30 (1), 117-128. http://dx.doi.org/10.1016/0047-2727(86)90081-2

This paper is posted at ScholarlyCommons. https://repository.upenn.edu/fnce_papers/186

For more information, please contact repository@pobox.upenn.edu. 


\title{
The Failure of Ricardian Equivalence Under Progressive Wealth Taxation
}

\author{
Abstract \\ Although the Ricardian Equivalence Theorem holds under a linear estate tax schedule, it fails to hold \\ under a nonlinear estate tax schedule. In a representative consumer economy, a temporary lump-sum tax \\ increase reduces contemporaneous consumption. If different consumers face different marginal estate \\ tax rates because they leave bequests of different sizes, a lump-sum tax increase redistributes resources \\ from consumers in low marginal estate tax brackets to consumers in high marginal estate tax brackets; \\ aggregate consumption may rise, fall, or remain unchanged. These departures from Ricardian \\ Equivalence hold more generally under any nonlinear tax on saving, wealth or income accruing to wealth. \\ Disciplines \\ Economics | Finance and Financial Management | Taxation
}


NBER WORKING PAPER SERIES

THE FAILURE OF RICARDIAN EQUIVALENCE UNDER

PROGRESSIVE WEALTH TAXATION

Andrew B. Abe 1

Working Paper No. 1983

NATIONAL BUREAU OF ECONOMIC RESEARCH

1050 Massachusetts Avenue

Cambridge, MA 02138

July 1986

The research reported here is part of the NBER's research program in Taxation. Any opinions expressed are those of the author and not those of the National Bureau of Economic Research. 
Working Paper \#1983

July 1986

The Failure of Ricardian Equivalence Under Progressive Wealth Taxation

\title{
ABSTRACT
}

Although the Ricardian Equivalence Theorem holds under a linear estate tax schedule, it fails to hold under a nonlinear estate tax schedule. In a representative consumer economy, a temporary lump-sum tax increase reduces contemporaneous consumption. If different consumers face different marginal estate tax rates because they leave bequests of different sizes, a lump-sum tax increase redistributes resources from consumers in low marginal estate tax brackets to consumers in high marginal estate tax brackets; aggregate consumption moy rise, fall, or remain unchanged. These departures from Ricardian Equivalence hold more generally under amy nonlinear tax on seving, wealth or income eccruing to wealth.

\author{
Andrew B. Abe 1 \\ Department of Economics \\ Littauer 111 \\ Harvard University \\ Cambridge, MA 02138
}


In a path-breaking paper, Robert Barro ( 1974) showed that if intergenerational altruism motivates consumers to leeve bequests, then changes in the timing of lum-sum taxes are irrelovant for the consumption decisions of individual consumers. The key insight in this demonstration of the Ricardian Equivalence Theorem is that if consumers derive utility from the utility of their heirs, as well as from their own consumption, then each (finitely-lived) consumer in an infinitely-lived family faces an infinite horizon problem when making his consumption and bequest decisions. Therefore, any change in the path of lump-sum taxes which leoves the present value of taxes unchanged does not affect the infinite-horizon intertemporal budget constraint and hence does not affect the optimal path of consumption.

Barro ( 1974) examined the effects of changes in the timing of lump-sum taxes in the presence of proportional inheritance taxes and concluded that "the existence of taxes on intergenerational transfers makes less likely an interior solution for the transfers, but if these transfers are operative, even if at reduced levels, the marginal effect of [changes in the timing of lump sum taxes] an consumption plans--and, hence, on r-- remains nil." (p. 1109) I will show below that this conclusion is incorrect, unless, as in Barro's formal analysis, the inheritance tax is a linear tax. However, most developed econom ies have a progressive tax on bequests, and the Ricardian Equivalence Theorem fails to hold in the presence of a nonlinear tax on bequests. Indeed, the presence of a nonlinear tax on any form of woalth, whother it is an intergenerational transfer or an individual's life-cycle seving, will lead to a violation of Ricardian Equivalence.

The literature on the aggregate implications of bequests contains models which display many important characteristics such as the endogeneity of the rate of return on savings (Buiter[ 1979], Carmichael [ 1982], Burbidge[ 1983], Abel [ 1985b]), the non-negativity constraint on bequests (Weil [ 1984]) and the uncertainty of the date of death (Abel $[1985 \mathrm{a}, \mathrm{b}]$ ); virtually all models in this literature include the over lapping nature of generations. Although each of these features of the economy has important implications which merit study, the model presented below will ignore all of them. The goal of this paper is to demonstrate clearly, in as simple a model as possible, that a 
nonlinear tax on inher itances, bequests, wealth or property income destroys the Ricardian Equivalence result. Furthermore, in a representative consumer framework, the direction of the departure from Ricardian Equivalence is unambiguous: with increasing marginal tax rates on inher itances, bequests, wealth or property income, a temporary tax increases reduces contemporaneous consumption.

The consumer's decision problem is presented in section I and the government budget constraint is presented in section II. Section III demonstrates that in a representative consumer economy with increasing marginal estate tax rates, an increase in the lump sum tax leads to a reduction in aggregate consumption. This effect ar ises because individual consumers are driven into lower marginal estate tax brackets and thus face a decrease in the price of their heirs' consumption relative to their own consumption. This relative price change leads to a decrease in current consumption. Section IV presents a second channel for the violation of Ricardian Equivalence: the cross-sectional variation in wealth implies that different consumers leave bequests of different sizes and hence face different marginal estate tax rates. An increase in the current lump-sum tax redistributes resources away from consumers in low marginal estate tax brackets to consumers in high marginal estate tax brackets; the effects on aggregate consumption are discussed in section IV. Section $V$ then argues that violation of Ricardian Equivalence ar ises more generally under any nonlinear tax on wealth or capital income. However, a nonlinear tax on labor income does not necessarily destroy Ricardian Equivalence es demonstrated in section VI. Concluding remarks are presented in section VII.

\section{The Consumption Decision}

Consider an economy which lests for only two periods--denoted as periods 1 and 2 . Individual consumers live for only one period. Each consumer who lives in period 1 has one child and this child is the consumer's only heir. Each consumer who lives during period $i(i=1,2)$ receives an endowment $e_{j}$, poys a lump-sum tax $T_{j}$, and consumes $c_{j}$. Period 1 consumers obtain utility from the utility of their heirs as well as directly from their own consumption. We specify the utility 
function of period I consumers to have the additively separable form

$$
u\left(c_{1}\right)+B u\left(c_{2}\right)
$$

where $u\left(c_{j}\right)$ is the utility that a consumer in period $i$ obtains from consumption in period $i$, and $B$ is a discount factor that a period 1 consumer applies to the utility of his heir.

Let $B$ denote the bequest left by a representative period 1 consumer so that

$$
B=e_{1}-T_{1}-c_{1}
$$

Let $R$ be the gross rate of return on assets (bequests). For simplicity, $R$ is fixed exogenously. Let I denote the inher itance received by a period 2 consumer. Suppose that an estate $\operatorname{tax} t(B)$ is levied on the bequest $B$ and that the marginal tax rate is non-negative, less than one, and is non-decreasing in $B$ ( that is, $0 \leq t^{\prime}<1$ and $t^{\prime \prime} 20$ ). The inheritance received by the period 2 consumer is $I=R[B-t(B)]$. Because the period 2 consumer has no heirs, he consumes all of his available resources so that

$$
c_{2}=R[B-t(B)]+e_{2}-T_{2}
$$

A periad 1 consumer maximizes the utility function in (1) subject to the budget constraint obtained by substituting (2) into (3). The first-order condition for this meximization problem is

$$
u^{\prime}\left(c_{1}\right)=B R u^{\prime}\left(c_{2}\right)\left(1-t^{\prime}(B)\right)
$$

The consumer equates the utility from consuming an extra unit in period 1 with the utility from bequeathing an extra unit, thereby increasing his heir's consumption by $\left(1-t^{\prime}\right) R$ units.

\section{The Government Budoet Constraint}

The Ricardian Equivalence Theorem is besed on the fact that individual consumers recognize that the government's intertemporal budget constraint implies that am/ rhange in current taxes must be offset, in present value, by a change in future taxes. 'If there are initially no government bonds outstanding, then the government's intertemporal budget constraint can be written as

$$
R\left[T_{1}+t(B)\right]+T_{2}=0
$$


Totally differentiating ( 5 ) with respect to $T_{1}, T_{2}$, and $B$ yields

$$
R\left[d T_{1}+t^{\prime}(B) d B\right]+d T_{2}=0
$$

In the next section we analyze the effect on consumption of changes in the lump-sum taxes $T_{1}$ and $T_{2}$ which satisfy (6).

\section{The Effect on Consumption of a Chanoe in Lump-Sum Taxes}

To calculate the effect of a lump-sum tax change on consumption, first observe from (2) that

$$
d c_{1}+d B=-d T_{1}
$$

Thus either $c_{1}$ or $B$ (or both) must fall in response to an increase in the lump-sum tax $T_{1}$. Next, observe from ( 3 ) that

$$
d c_{2}=R\left[d B-t^{\prime}(B) d B\right]-d T_{2}
$$

Substituting the government budget constraint (6) into ( 8 ), and using (7), yields

$$
d c_{2}=-R d c_{1}
$$

An individual consumer can, at the margin, increase $c_{2}$ and reduce $c_{1}$ in the ratio $\left(1-t^{\prime}(B)\right) R$; however, in comparing the new equilibrium with the initial equilibrium, $c_{1}$ and $c_{2}$ change in the ratio $R$, which is the inter temporal price of $c_{2}$ relative to $c_{1}$ for the economy as a whole. ${ }^{2}$

To calculate the changes in $c_{1}$ and $c_{2}$, define $g(c)=-u^{\prime \prime}(c) / u^{\prime}(c)>0$. Logarithmically differentiating both sides of the first-order condition (4) yields

$$
g\left(c_{1}\right) d c_{1}=g\left(c_{2}\right) d c_{2}+\left[t " /\left(1-t^{\prime}(B)\right)\right] d B
$$

Using (7) to substitue for $d B$ and (9) to substitute for $d c_{2}$, equation (10) can be written as

$$
-1<d c_{1} / d T_{1}=-t^{\prime \prime} /\left\{\left(1-t^{\prime}\right)\left[g\left(c_{1}\right)+\operatorname{Ro}\left(c_{2}\right)\right]+t^{\prime \prime}\right\} \text { s } 0
$$

where the inequalities in (11) follow from $0 \leq t<1, t " \geq 0$ and $g(c)>0$. It follows from (11) that if the estate tax is linear $(t=0)$, then Ricardian Equivalence holds. However, if the estate tax is char acter ized by a rising marginal rate, then an increase in the first-period lump-sum tax leads to a decrease in first-period consumption. The direction of the effect of the first-period tax on first-period consumption is the same as would be predicted by a naive application of a "Keynesian" 
consumption function relating consumption to contemporaneous disposable income.

The intuition behind the failure of Ricardian Equivalence is straightforward. If Ricardian Equivalence were to hold so that $c_{1}$ and $c_{2}$ were invariant to the change in $T_{1}$, then an increase in $T_{1}$ would reduce the bequest $B$ and hence would reduce the marginal tax rate $t$ ', if $t$ " $>0$. The effect of the decrease in $t^{\prime}$ is to increase the utility associated with decreasing $c_{1}$ by one unit and increasing $c_{2}$ by $\left(1-t^{\prime}\right) R$ units. Put differently, the effect of the decrease in $t^{\prime}$ is to reduce the price of the heir's consumption relative to the consumer's own consumption. Hence, the consumer responds to this intertemporal price change by reducing $c_{1}$ and increasing $c_{2}$.

The reduction in $c_{1}$ is smaller then the increase in $T_{1}$. To understand this result, suppose that the reduction in $c_{1}$ were equal to the increase in $T_{q}$. In this case, the bequest $B$ would be unchanged and the intergenerational terms of trade $\left(1-t^{\prime}\right) R$ would be unchanged. But if the intergenerational terms of trade are unchanged, and if the present value of taxes is unchanged, then the optimal response of $c_{1}$ to the change in $T_{1}$ is zero rather one-for-one.

The results implied by equation ( 11 ) are derived under the assumption that the estate tax is a twice differentiable function of the bequest. However, actual tax codes generally specify marginal tax rates ( $t$ ') as step functions of the tax base. Thus, at any given tax base, the slope of the marginal tax function ( $t$ ") is either zero or is undefined. Therefore, a literal interpretation of (11) may lead one to conclude (incorrectly) that the nonlinearity in actual tax codes does not destray Ricardian Equivalence. However, Ricardian Equivelence will fail to hold if, by maintaining current consumption unchanged, the representative consumer is driven into a lower (marginal) tax bracket by the lump-sum tax increase. The grester is the increase in the first-period tax, the greater is the likelihood that the representative consumer will be driven into a lower marginal tax bracket.

\section{Cross-Sectional Yariation in /nitial Wealth}

With a nonlinear estate tax schedule, there are two sources of variation in marginal tax rates 
which can destroy the irrelevance of lump-sum tax changes. In section III we focussed on the variation in the marginal estate tax rate faced by an individual consumer as the lump-sum taxes are varied. Amy change in the marginal estate tax rate faced by a consumer implies a change in the intergenerational terms of trade and thus causes a change in the intergenerational allocation of consumption. Alternatively, in this section we consider the cross-sectional variation in marginal estate tax rates which ar ises because otherwise identical first-period consumers have different levels of initial wealth or endowments. The presence of cross-sectional variation in marginal estate tax rates implies that a non-discriminatory increase in the first-period lump-sum tax, $T_{1}$, induces a redistribution of weslth from families with low marginal tax rates to families with high marginal tax rates. This redistribution ar ises because the tax $T_{1}$ generates a deduction from the taxable estate. The size of the reduction in estate taxes generated by a given increase in $T_{1}$ is an increasing function of the marginal estate tax rate so that an intertemporally balanced-budget lump-sum increase in $T_{1}$ shifts resources towards families with high marginal estate tax rates.

To keep the analysis simple, we assume that the marginal tax rate schedule is a step function of the size of the bequest. Furthermore, we assume that the bequest left by each consumer is sufficiently far from the next tax bracket, and that the change in the lump-sum tax is sufficiently small, so that no consumers are oriven into different tax brackets as a result of the tax change. Formally, these assumptions imply that for the relevant values of the bequests, $t "=0$.

Suppose that all first-period consumers are identical in all respects except for the initial endowment $e_{1}$. Suppose that there are $J$ possible values of the first-period endowment $e_{j}, j=$ $1, \ldots, \mathrm{J}$. We will refer to a consumer who receives an endowment $e_{j 1}$ as a type $j$ consumer. Let $s_{j}$ denote the fraction of first-period consumers who are of type $j$, so that $\Sigma_{j} s_{j}=1$. Equation $(10)$ in section III holds for each type of consumer. Setting $t "=0$, dividing $(10)$ by $\approx\left(c_{j 2}\right)$ and using $(7)$ and ( 8 ) to substitute for $d_{2}$ yields

$$
\left[g\left(c_{j 1}\right) / g\left(c_{j 2}\right)+R\right] d c_{j 1}=-\left\{R\left[d T_{1}+t^{\prime}\left(B_{j}\right) d B j\right]+d T_{2}\right\}
$$

where the subscript $j$ denotes that a variable pertains to a type $j$ consumer. Note that the 
lump-sum taxes $T_{1}$ and $T_{2}$ are not subscripted by $j$ because we are confining our attention to lump-sum tax policies which do not discriminate across consumers of different types.

The government's budget constraint in ( 5 ) must be modified to take account of the different estate tax payments by different types of consumers

$$
R\left[T_{1}+\Sigma_{j} s_{j} t\left(B_{j}\right)\right]+T_{2}=0
$$

Totally differentiating the government budget constraint (13) with respect to $T_{1}, T_{2}$, and $B_{j}$, and using the fact that $\Sigma s_{j}=1$, yields

$$
\sum s_{j}\left\{R\left[d T_{1}+t^{\prime}\left(B_{j}\right) d B_{j}\right]+d T_{2}\right\}=0
$$

Let $d C_{1}=\Sigma s_{j} d c_{j}$ be the change in aggregate first-period consumption. It follows immediately from (12) that

$$
d c_{1}=-\Sigma s_{j}\left\{R\left[d T_{1}+t^{\prime}\left(B_{j}\right) d B_{j}\right]+d T_{2}\right\} /\left[g\left(c_{j 1}\right) / g\left(c_{j 2}\right)+R\right]
$$

If $g(c)$ is constant, then it follows from (15) and the government budget constraint (14) that $d c_{1}=0$. Although aggregate consumption is unchenged when $\mathscr{\theta}(c)$ is constant, the Ricardian Equivalence Theorem does not hold because an increase in $T_{1}$ and the associated reduction in $T_{2}$ redistribute resources from families with low marginal estate tax rates to families with high marginal estate tax rates. Therefore, consumers with high marginal tax rates increase their consumption and consumers with low marginal tax rates decrease their consumption.

In gener al, aggregate first-period consumption changes in response to a change in lump-sum taxes which obeys the government budget constraint. Since the coefficient of $\mathrm{dc}_{j}$ on the left hand side of (12) is positive, the sign of the right hand side of $(12)$ is the same as the sign of dgy. Substituting (7) into (12) we obtain

$$
\left[x\left(c_{j 1}\right) / g\left(c_{j 2}\right)+\left(1-t_{j}\right) R\right] d c_{j 1}=-\left\{R\left(1-t_{j}{ }^{\prime}\right) d T_{1}+d T_{2}\right\}
$$

If $d T_{1}>0$, then the right hand side of $(16)$ is increasing in $t_{j}$. Therefore, there exists $8 j^{*}$ such that

$$
\begin{array}{llllll}
d c_{j 1} \leq 0 & \text { and } & -R\left[d T_{1}+t^{\prime}\left(B_{j}\right) d B_{j}\right]+d T_{2} & \leq 0 & \text { if } & t_{j} \leq t_{j}^{*} \\
d c_{j 1}>0 & \text { and } & -R\left[\sigma_{1}+t^{\prime}\left(B_{j}\right) d B_{j}\right]+d T_{2}>0 & \text { if } & t_{j}^{\prime}>t_{j}^{*}
\end{array}
$$


If $g\left(c_{j 1}\right) / g\left(c_{j 2}\right)$ is decreasing (increasing) in $t_{j}$, then the weight $\left[g\left(c_{j 1}\right) / g\left(c_{j 2}\right)+R\right]^{-1}$ in the weighted sum (15) is increasing (decreasing) in $t_{j}$ ' so that, from $(17 a, b)$ the positive values of $-R\left[d T_{1}+t^{\prime}\left(B_{j}\right) d B_{j}\right]+d T_{2}$ receive larger (smaller) weights and hence the value of $d_{1}$ in (15) is positive (negative). As an example, consider the isoelestic utility function $u(c)=$

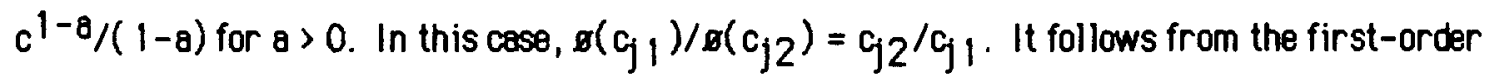
condition (4) that $c_{j 2} / c_{j 1}=\left[B R\left(1-t_{j}{ }^{j}\right)\right]^{1 / \theta}$ so that $g\left(c_{j 1}\right) / B\left(c_{j 2}\right)=\left[B R\left(1-t_{j}^{\prime}\right)\right]^{1 / a}$ is a decreasing function of $t^{\prime} j$. Therefore, an increase in $T_{1}$ leads to an increase in aggregate first-period consumption. This result contredicts both the Ricardian Equivalence Theorem and the prediction from a straightforward application of a "Keynesian" consumption function.

\section{Extensions to Progressive Wealth and Capital Uncome Taxes}

The literature on the effects of changes in lump-sum tax and transfer policy has focussed on the role of, and motivation for, voluntary private intergenerational transfers. The reason for this focus can be traced to Diamond's (1965) seminal paper with finitely-lived consumers who do not leave bequests. The Diamond model providad a coherent general equilibrium framework with maximizing firms and consumers in which lump-sum changes in the government's financial policy have real effects. Subsequently, Barro( 1974) showed that if consumers have operative bequest motives arising from intergenerational altruism, then lump-sum changes in the goverment's financial policy are irrelevent. Since the appearance of Barro's paper, the question of Ricardian equivalence has revolved largely around the role of intergenerational transfers. ${ }^{3}$ It is in keeping with the spirit of this literature that I interpreted the model presented above in terms of a nonlinear tax on bequests. However, it is not the tax on bequests per 28 which leads to the effects of intertemporally balanced-budget changes in lump-sum taxes. The model presented above could alternatively be interpreted as applying to an economy in which all consumers live for two periods and leave no bequests. In this case, the tax $t(B)$ is to be interpreted as a tax on wealth or seving.

If we interpret the model presented above as applying to consumers who live for two periods, 
then it may be more relevant to interpret the results as applying to an economy with a nonlinear property income tax rather than a wealth tax. In this case, the ver iable $B$ would be interpreted as saving at the end of the first period, and $(R-1) B$ is property income. Letting $t *((R-1) B)$ be the property income tax, the first-order condition (4) must be amended to

$$
u^{\prime}\left(c_{1}\right)=\beta\left[R-(R-1) t^{*}\right] u^{\prime}\left(c_{2}\right)
$$

Logar ithmically differentiating ( 18 ) with respect to $c_{1}, c_{2}$, and $B$ yields

$$
\boldsymbol{\theta}\left(c_{1}\right) d c_{1}=\boldsymbol{g}\left(c_{2}\right) d c_{2}+\Omega(B) d B
$$

where

$$
\Omega(B)=\left[(R-1)^{2} t^{*} "\right] /\left[R-(R-1) t^{*}\right]
$$

Using (9) to eliminate $d c_{2}$ and (7) to eliminate $d B$, we obtain 4

$$
\left\{g\left(c_{1}\right)+R g\left(c_{2}\right)+\Omega(B)\right\} d c_{1}=-\Omega(B) d T_{1}
$$

Recalling that $0 \leq t^{*}<1$ and that $t^{*} \geq 0$, it follows from (19b) that $\Omega(B) \geq 0$ with strict inequality if $t^{*} ">0$. Therefore, $(20)$ implies that $-1<d c_{1} / d T_{1} \leq 0$, with strict inequality if $t^{*} ">0$. Thus, for an economy with a representative consumer, the effects of lump-sum tax changes in the presence of a nonlinear property income tax are qualitatively the same as the effects in the presence of a nonlinear estate tax as derived in section III.

\section{Vl. Labor Income Iaxes}

It is well-known that changes in the structure of distortionary (non-lump-sum) taxes will affect the allocation of consumption. For example, Carmichæl (1982) and Burbidge (1983) hove each shown that if labor supply is a choice variable of individual consumers, then changes in the tax rate on labor income affect the allocation of consumption and output. The implication drawn by Burbidge (1983) is that government "debt is not neutral once one permits a labor-leisure choice to the young who pay taxes on their earnings." (p.226) However, if tax revenue is raised by both lump sum taxes and labor income taxes, then Burbidge's result must be modified: If the government finances a current tax cut by issuing bonds, then government debt will be neutral if the labor income tax schedule is unchanged. That is, changes in the timing of lump sum taxes have no effect on the allocation of consumption if the only other tax is a labor income tax. This result holds 
whether the labor income tax is linear or nonlinear.

To establish the modification of Burbidge's result, let $L_{i}$ be the labor supply of an individual in period $i$, and let $w_{j}$ be the (exogenous) pre-tax real wage rate in period $i s 0$ that $w_{j} L_{i}$ is labor income in period $i$. Then, letting $t_{L}(w L)$ be the labor income tax, and assuming that the only other tax is a head tax, we can modify equations (1) - (4) to write the maximization problem of a period 1 consumer as

$$
\max u^{*}\left(c_{1}, L_{1}\right)+B u^{*}\left(c_{2}, L_{2}\right)
$$

s.t. $c_{2}=R\left[e_{1}+w_{1} L_{1}-t_{L}\left(w_{1} L_{1}\right)-T_{1}-c_{1}\right]+e_{2}+w_{2} L_{2}-t_{L}\left(w_{2} L_{2}\right)-T_{2}$

The first-order conditions are

$$
\begin{aligned}
-u_{L i}^{*} / u^{*}{ }_{c i} & =\left[1-t_{L}{ }_{L}\left(w_{j} L_{j}\right)\right] w_{j} \quad i=1,2 \\
u^{*}{ }_{C l} & =B R u^{*}{ }_{C 2}
\end{aligned}
$$

The government budget constraint is

$$
R\left[T_{1}+t_{L}\left(w_{1} L_{1}\right)\right]+T_{2}+t_{L}\left(w_{2} L_{2}\right)=0
$$

If $\mathrm{RdT} T_{1}+\mathrm{dT}_{2}=0$, then it is both feesible and optimal for consumers to maintain the initial values of $c_{j}$ and $L_{i}$. Because consumers continue to earn the same labor income and pay the same labor income taxes, the government budget constraint will be satisfied.

The analysis in this section illustrates that Ricardian Equivalence is not necessarily destroyed by the existence of (linear or nonlinear) labor income taxes if the government also has access to lump sum taxes. This finding is to be contrested with the results in previous sections in which the existence of a nonlinear tax on wealth, saving, property income, inheritances or bequests leads to 8 violation of Ricardian Equivalence. The difference in the results is due to the fact that Ricardian Equivalence requires consumers to change their path of wealth accumulation to maintain unchenged consumption in the face of a tax change. If there is a nonlinear tax on wealth or income accruing to wealth, then changes in wealth accumulation will change intertemporal prices and render the initial allocation of consumption suboptimal. However, changes in the pattern of wealth accumulation have no effect on the price of leisure implied by the labor income tax. 


\section{Vll. Conclusion}

This paper has explored the implications of increasing marginal tax rates on bequests, inher itances, property income and wealth for the efficacy of lump-sum tax and transfer policies. We demonstrated that the Ricardian Equivalence Theorem fails to hold in the presence of nonlinear taxes on bequests, inheritances, property income or wealth. It is important to note that the breakdown of Ricardian Equivalence results from the nonlinearity in the estate tax; with a constant marginal tax rate, Ricardian Equivalence is preserved under the standard set of assumptions. There are two channels by which lump-sum tax and transfer policies are effective in the presence of a nonlinear tax. First, the marginal tax rate can vary for an individual as his wealth varies. Second, the marginal tax rate can vary cross-sectionally across consumers with different levels of wealth.

In an economy with identical consumers, the only source of variation in the marginal estate tax rate is variation in the wealth of the representative consumer. If the Ricardian Equivalence Theorem were to hold in such an economy, then a lump-sum tax increase would reduce contemporaneous savings as consumers maintained an unchanged allocation of consumption over time. However, the reduction in savings implies a reduction in the consumer's estate and hence a reduction in the marginal estate tax rate. This reduction in the marginal estate tax rate reduces the pricolf the consumer's heir'sconsumption relative to the price of the consumer's own consumption. Thus, the consumer is induced to increase his bequest at the expensive of reducing his own consumption. This result is qualitatively the same as predicted by a simple Keynesian consumption fucntion relating consumption to contemporaneous disposable income.

The cross-sectional variation in marginal estate tax rates which ar ises from cross-sectional variation in wealth implies that changes in the timing of lump-sum taxes will induce redistributions of resources across families with different marginal estate tax rates. In particular, an increase in the current lump-sum tax will fall more heavily on families with low marginal tax rates than on families with high marginal tax rates. This redistr ibution of resources will undoubtedly affect the cross-sectional allocation of consumption. Whether aggregate 
consumption is affected by a contemporaneous change in the lump-sum tax depends on the utility functions of consumers. If the instantaneous utility function displays constant absolute risk oversion, and if the tax change is small enough so that all consumers remain in their initial estate tax brackets, then aggregate consumption is unaffected by the lump-sum tax change. However, this finding should not be viewed as a vindication of the Ricardian Equivalence Theorem, because the zero change in aggregate consumption masks changes in the consumption of individual consumers. More generally, aggregate consumption as well as the cross-sectional allocation of consumption will change in response to a change in lump-sum taxes.

As explained in section $V$, the historical development of the literature has led to a strong link between Ricardian Equivalence and the existence of bequests motivated by intergenerational altruism. We have shown that the presence of a nonlinear tax on bequests destroys the Ricardian Equivalence Theorem. Moreover, it is not the nonlinear tax on bequests per se which is important; Ricardian Equivalence will fail to hold whenever there is a nonlinear tax on saving or the income accruing to saving. The key question is whether a change in the timing of lump-sum taxes leads to an optimal intertemporal reallocation of consumption within the consumer's family. If there is such an aptimal reallocation, then Ricardian Equivalence is violated regardless of whether the reallocation is across different generations of the family or across different periods of a consumer's life. 
References

Abel, Andrew B., 1985a, Precautionary Saving and Accidental Bequests, American Econom ic Review $75,777-791$.

Abel, Andrew B., 1985b, Fiscal Policy under Concave Altruism, mimeo Harvard University.

Barro, Robert J., 1974, Are Government Bonds Net Wealth?, Journal of Political Economy 82, $1095-1117$.

Barro, Robert J., 1976, Reply to Feldstein and Buchanan, Journal of Political Economy 84 , 343-349.

Barsky, Robert, N. Gregory Mankiw and Stephen Zeldes, 1984, Ricardian Consumers with Keynesian Propensities, mimeo, Massachusetts Institute of Technology.

Bernheim, B. Douglas and Kyle Bagwell, 1984, Is Everything Neutral? The Implications of Intergenerational Altruism in an Over lapping Generations Model with Marriage, mimeo, Stanford University.

Buiter, Willem H., 1979, Government Finance in an Over lapping-Generations Model with Gifts and Bequests, in: George M. vanFurstenburg, ed., Social Security versus Private Saving, (Ballinger, Cambridge, Massachusetts) 395-429.

Burbidge, John B., 1983, Government Debt in an Over lapping-Generations Model with Bequests and Gifts, American Economic Review 73, 222-227.

Carmichael, Jeffrey, 1982, On Barro's Theorem of Debt Neutrality: The Irrelevance of Net Wealth, American Economic Review 72, 202-213.

Diamond, Peter A., 1965, National Debt in a Neoclassical Growth Model, American Economic Review $55,1126-1150$

Feldstein, Martin S., 1976, Perceived Wealth in Bonds and Social Security, Journal of Political Economy $84,331-333$.

Weil, Philippe, 1984, Love Thy Children: Reflections on the Barro Debt Neutrality Theorem, mimeo, Harvard University. 
Footnotes

* I thank an anomymous referee for helpful comments and the National Science Foundation for financial support.

1. It is possible in an infinite-horizon model for the government to reduce current taxes without having to increase future taxes at any date if the interest rate is smaller than the population growth rate. (See Barro( 1976), Feldstein( 1976) and Carmicheel( 1982)). This consideration does not arise in the two-period economy in this paper.

2. We have assumed that all consumers know the government budget constraint and correctly anticipate the second-period tax $T_{2}$. However, we assume that individual consumers behave atomistically: in choosing $B$, individual consumers take $T_{1}$ and $T_{2}$ as parametrically given since no consumer is large enough to affect per capita revenues by his actions alone. If there were only one consumer in the economy, then his behavior would affect $T_{1}$ and $T_{2}$. In this case, substituting the government budget constraint (5) into the consumer's budget constraint (from (2) and (3)) would yield $c_{2}=R\left(e_{1}-c_{1}\right)+e_{2}$, and Ricardian Equivalence would hold in this case with a single consumer.

Alternatively, the Ricardian Equivalence Theorem would hold in the presence of lump-sum texes if all families were effectively linked to one another by operative intergenerational transfers. Bernheim and Begwell ( 1984) have argued that such linkages will be important because people from different femilies marry and have children. However, if one takes the Bernheim-Bagwell results seriously, then not only are lump-sum taxes irrelevant, but the price system is also irrelevant. The implication which Bernheim and Bagwell draw from these overly strong results is that bequests must be generated by motives other than (possibly in addition to) altruism.

3. Barsky, Mankiw, and Zeldes ( 1984) is an interesting exception. 
4. Equation (9) holds under a property income tax as well as under an estate tax. With a property income tax, the budget constraint of an individual consumer implies

$$
d c_{2}=\left[R-(R-1) t^{*}\right] d B-d T_{2} .
$$

The government budget constraint is $R T_{1}+t^{*}((R-1) B)+T_{2}=0$, which can be totally differentiated with respect to $T_{1}, T_{2}$ and $B$ to yield

$$
R \mathrm{dT}_{1}+(\mathrm{R}-1) \mathrm{t}^{* \prime} \mathrm{dB}+\mathrm{dT}_{2}=0 \text {. }
$$

Combining equations ( $f 4.1$ ) and ( $f 4.2$ ) and using ( 7 ) yields ( 9 ). 